
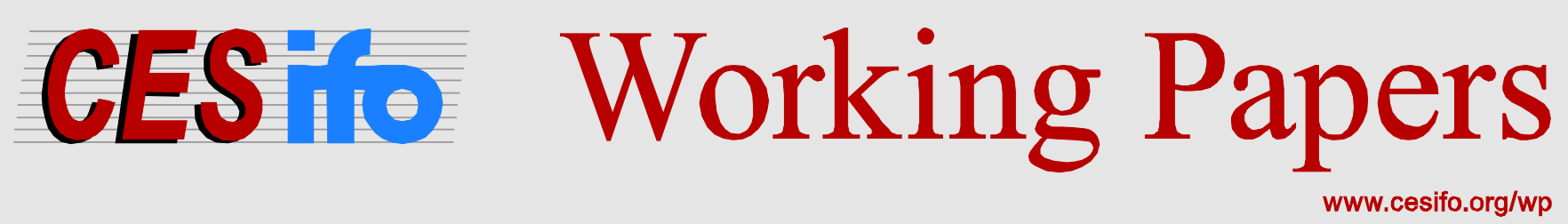

\title{
Do Politicians Reward Core Supporters? Evidence from a Discretionary Grant Program
}

\author{
Björn Kauder \\ Niklas Potrafke \\ Markus Reischmann
}

CESIFO WORKING PAPER NO. 6097

CATEgory 2: Public CHOICE

SEPTEMBER 2016

An electronic version of the paper may be downloaded

- from the SSRN website:

- from the RePEc website:

- from the CESifo website: WwW.SSRN.com

www.RePEc.org

www.CESifo-group.org/wp

ISSN 2364-1428 


\title{
Do Politicians Reward Core Supporters? Evidence from a Discretionary Grant Program
}

\begin{abstract}
We investigate whether politicians award intergovernmental grants to core supporters. Our new dataset contains information on discretionary project grants from a German state government to municipalities over the period 2008-2011. The results show that discretionary grants were awarded to municipalities with many core supporters of the incumbent state government. Discretionary grants per capita increased by about 1.4 percent when the vote share of the incumbent party in the state election increased by one percentage point. The fiscal capacity of a municipality does, by contrast, not predict the level of discretionary grants. We propose to trim discretionary project grants to the benefit of formula-based grants.
\end{abstract}

JEL-Codes: D720, H720, H770, H810.

Keywords: intergovernmental grants, discretionary grants, fiscal equalization, core supporters, electoral motives.

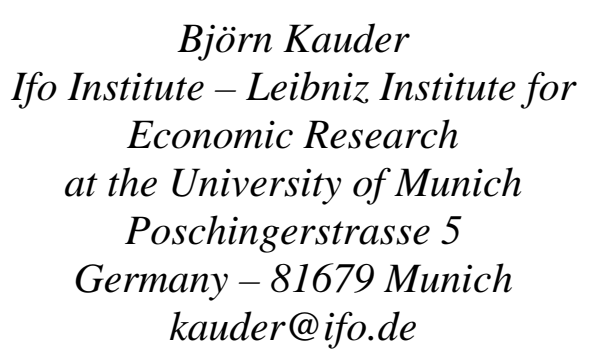

Markus Reischmann

Ifo Institute - Leibniz Institute for

Economic Research

at the University of Munich

Poschingerstrasse 5

Germany - 81679 Munich

reischmann@ifo.de

\footnotetext{
*corresponding author
} 


\section{Introduction}

Politicians are likely to influence intergovernmental grants for many reasons. It is conceivable that politicians influence the distribution of grants to favor their home towns or to favor municipalities where a politician from their own party is in office (party alignment). To increase election prospects, federal and state politicians may award grants to municipalities with many swing voters. Politicians may, however, also direct grants to their core supporters by favoring municipalities where the vote share of the own party is large. The model of Cox and McCubbins (1986) describes that politicians award benefits to core supporters when both the expected vote share and uncertainty enter the politicians' calculus. An intriguing question therefore is whether politicians actually direct intergovernmental grants to core constituencies.

The extent to which politicians influence grants depends on the policy instruments available to the politician. It is much more difficult to influence grant schemes that follow established formulae than to use discretionary grants. Naturally, for the purpose of an empirical analysis, "one would like to have a grant program over which the incumbent government has full discretionary power" (Johansson 2003: 889). Data on the German state Rhineland-Palatinate allows us to investigate the distribution of discretionary project grants directed by the state government to the municipalities. We also use data for formula-based grants.

Grant distribution by the government in Rhineland-Palatinate was a widely discussed issue in the media. In 2007, for example, the municipality Bad Bergzabern decided to support a private investor financially to convert an outbuilding of a historic castle into a (privately owned) hotel - justified with the negative externalities of a ruinous building next to a landmark in the historic center of the city. For that purpose of urban renewal, the municipality later received discretionary grants worth 1.875 million euros (251 euros per capita). It leaked out that the administration office to which the state government delegated the handling of 
grant applications had serious misgivings about the economic efficiency of the investment. Being subject to the ministries' directives, however, the administration eventually promoted the grant. In Rhineland-Palatinate the state government has the greatest leeway in awarding grants for urban renewal of all German states (Rechnungshof Rheinland-Pfalz 2011).

Investigating how grants were distributed in the state Rhineland-Palatinate is a worthwhile endeavor for two more reasons: firstly, the state consists of more municipalities $(2,306)$ than any other German state, which allows exploiting wide-scale variation. Secondly, the incumbent party (Social Democratic Party - SPD) has been in office since 1991, which means that the government has networks and a sound knowledge of distributing grants.

By exploiting a new dataset, we examine whether municipalities with many core supporters of the state incumbent party received more discretionary grants from the state level in Rhineland-Palatinate. Our results show that grants were indeed awarded especially to municipalities with many core supporters of the state incumbent party. The fiscal capacity of a municipality does, by contrast, not predict the level of discretionary grants. The results do also not show that politicians manipulated formula-based grants.

\section{Prior studies and our hypothesis}

Experts investigate whether electoral and other political motives influence how politicians distribute intergovernmental grants. ${ }^{1}$ The model of Weingast et al. (1981) describes that, when deciding on projects to be directed to individual electoral districts, political representatives favor projects in their own district. Such pork-barrel spending gives rise to inefficiencies. ${ }^{2}$

\footnotetext{
${ }^{1}$ Intergovernmental grants may also be influenced by direct democracy (Feld and Schaltegger 2005), voter turnout (Martin 2003), lobbying by local politicians (Borck and Owings 2003, Dalle Nogare and Kauder 2016), the electoral geography of districts (Chen 2010), and legislative representation (Knight 2008). See Curto-Grau et al. (2012) on the distribution of spending in semi-democratic Spain. Grants may in turn "mobilize" voters and thus give rise to higher voter turnout (Ansolabehere and Snyder 2006, Vicente 2014).

${ }^{2}$ For studies investigating a home-district or home-town bias, see Jennes and Persyn (2015) for Belgium, Stratmann and Baur (2002) and Maaser and Stratmann (2014) for Germany, Sjahrir et al. (2015) for Indonesia, Carozzi and Repetto (2016) for Italy, Horiuchi and Saito (2003) for Japan, Fiva and Halse (in press) for Norway,
} 
When the same party controls a jurisdiction's legislature and the legislature of the next-higher level of government (partisan alignment), the jurisdiction may also receive more grants (see, e.g., Sengupta 2011). ${ }^{3}$

An issue in the extant literature is whether politicians should focus on core supporters or on swing voters to maximize election prospects. ${ }^{4}$ In Lindbeck and Weibull's (1987 and 1993) and Dixit and Londregan's (1996 and 1998) “swing-voter model”, two parties (or two blocs of parties) maximize their vote shares by tactically redistributing grants to election districts with many swing voters, i.e. voters that are indifferent between the two parties ("cutpoint voters"), to win the election. Because the number of swing voters is difficult to measure, empirical studies often use the closeness of an election as a proxy for the number of swing voters, assuming a symmetric and single-peaked distribution of preferences. Many empirical studies corroborate the swing-voter model. ${ }^{5}$

In Cox and McCubbins' (1986) “core-supporter model”, by contrast, politicians can invest in support groups, in swing groups, and in opposition groups. Investing in support groups is less risky than investing in swing groups because politicians may well assess how their core supporters react (to grants), whereas swing voters are unattached to politicians by definition. Risk-averse politicians will thus - in terms of an expected-vote calculus - "tend to over-invest in their closest supporters" (distribute grants primarily to constituencies with many core supporters), "just as risk-averse investors will tend to over-invest in low-risk securities" (p. 385). Empirical studies typically use the vote share of a party as a proxy for the

Anderson and Tollison (1991), Ansolabehere et al. (2002), Atlas et al. (1995), and Knight (2002 and 2004) for the United States, and Hodler and Raschky (2014) for developing countries.

${ }^{3}$ On the effects of partisan alignment, see Worthington and Dollery (1998) for Australia, Brollo and Nannicini (2012) for Brazil, Cadot et al. (2006) for France, Kemmerling and Stephan (2002) for Germany, Arulampalam et al. (2009) for India, Bracco et al. (2015) for Italy, Veiga and Pinho (2007) for Portugal, Curto-Grau et al. (2014), Solé-Ollé (2013), and Solé-Ollé and Sorribas-Navarro (2008) for Spain, and Albouy (2013), Geys and Vermeir (2014), Gist and Hill (1984), Grossman (1994), and Levitt and Snyder (1995) for the United States.

${ }^{4}$ On the personality traits of core supporters and swing voters, see Aidt and Rauh (2015).

${ }^{5}$ See, e.g., Case (2001) for Albania, Litschig (2012) for Brasil, Cadot et al. (2006) for France, Banful (2011) for Ghana, Arulampalam et al. (2009) for India, Helland and Sørensen (2009) for Norway, Veiga and Pinho (2007) for Portugal, Solé-Ollé (2013) for Spain, Johansson (2003) for Sweden, and Wright (1974) for the United States. 
number of core supporters and find mixed evidence. US congressional districts where the number of voters of the incumbent federal government was high obtained more federal domestic assistance program grants (Levitt and Snyder 1995) and a larger share of discretionary project-grant funding (Stratmann and Wojnilower 2015). US presidents gratified core partisan counties in swing states (Kriner and Reeves 2015); also state governments gratified core supporter counties (Ansolabehere and Snyder 2006). In Québec, electoral districts with many core supporters of the incumbent provincial government received more spending on roads (Joanis 2011). In France, transportation infrastructure investments were shown to be higher in districts with a large vote share of the incumbent national government (Cadot et al. 2006). Studies on local investment programs in Swedish municipalities and infrastructure investments in Spanish regions did not, however, find evidence that governments reward core supporters (Dahlberg and Johansson 2002 and Castells and Solé-Ollé 2005). ${ }^{6}$

Following the related studies, we examine whether the state government in RhinelandPalatinate distributed discretionary grants to municipalities with many core supporters. Were grants per capita higher in municipalities where the state's incumbent party had a large share of the votes? We test this hypothesis based on state election outcomes. To be sure, higher grants per capita in municipalities with a large vote share of the state incumbent do not necessarily describe political manipulation. We cannot rule out that these municipalities applied for more project grants or for grants for more eligible projects than other municipalities. In any event, this would still indicate that municipalities with many core supporters received more grants per capita.

\footnotetext{
${ }^{6}$ Related to the concept of core supporters, Stratmann (1996) examines how re-election constituencies influence voting in the U.S. Congress and contribution strategies of political action committees.
} 


\section{Institutional background}

\subsection{The state and municipalities of Rhineland-Palatinate}

The state Rhineland-Palatinate is an intriguing subject for studying the distribution of grants for three reasons. Firstly, the state government is in charge of a discretionary grant system that distributes money from the state level to the municipalities. Secondly, RhinelandPalatinate is the state with the largest number of municipalities $(2,306)$ in Germany, which differ in several characteristics such as population (varying from 11 to 197,640 inhabitants), fiscal capacity, and political preferences. Thirdly, the state incumbent party has been in power since 1991. An issue therefore is whether the incumbent party has institutionalized the grant system for rewarding core constituencies.

The municipalities are responsible for many policy fields such as individual parts of social security, schooling, housing, cultural policy, and refuse management. About a third of the average budget of municipalities in Rhineland-Palatinate stems from grants from the state level. The remaining parts of the average budget include tax revenues, other revenues, and grants from other levels than the state level. The local business tax and the property taxes are the most important autonomous taxes, while the municipalities also obtain shares from the (federal) income tax and the (federal) sales tax.

In Rhineland-Palatinate there are four types of municipalities, which differ in the extent of their policy autonomy: 12 county-independent cities ("kreisfreie Städte"), 8 large cities that are not county-independent (“große kreisangehörige Städte”), 28 municipalities of intermediate size ("verbandsfreie Gemeinden"), and 2,258 small municipalities ("Ortsgemeinden"). ${ }^{7}$ Small municipalities form 163 associations ("Verbandsgemeinden"), which are responsible for individual policy fields concerning several small municipalities.

\footnotetext{
${ }^{7}$ County-independent cities have additional responsibilities as compared to cities that are part of a county. On city size and the demand for local public goods see Buettner and Holm-Hadulla (2013).
} 


\subsection{The voting system}

State elections take place every five years. Voters cast two votes in a personalized proportional representation system. The first vote determines which candidate is to obtain the direct mandate in one of the 51 constituencies with a relative majority. The second vote determines how many seats the individual parties receive in parliament. Each party that received at least 5 percent of the second votes obtains a number of the 101 seats in the parliament that corresponds to the party's second vote share. ${ }^{8}$ Candidates voted into the parliament with the first vote (direct mandate) receive their seats first. Candidates from party lists receive the remaining seats. When the number of direct mandates exceeds the party's second vote share, the party obtains excess mandates. The other parties then obtain equalizing mandates to balance the power relations, which can enlarge the parliament.

Local council elections also take place every five years. All municipalities hold local council elections on the same day. In the vast majority of municipalities (all "small municipalities"), mayors are elected on the same day as the local council. In cities and municipalities of intermediate size, mayors are elected every eight years.

\subsection{The political party landscape}

Two major political parties characterize the political spectrum in Rhineland-Palatinate: the Social Democratic Party (SPD) and the Christian Democratic Union (CDU). All state prime ministers until 1991 were members of the CDU, while all state prime ministers as of 1991 were members of the SPD. The much smaller Free Democratic Party (FDP) played an important role as coalition partner for both SPD and CDU. In our legislative period of interest (2006-2011), the SPD formed a government without a coalition partner based on a majority of 52 percent of seats in parliament after a landslide victory in the 2006 state election. In the

\footnotetext{
${ }^{8}$ Candidates obtain a direct mandate even if their party failed to reach the 5 percent clause.
} 
2011 state election, the SPD lost many votes - maybe because the grant distribution was widely discussed in the media (see introduction) - and has since then for the first time formed a coalition with the Greens (Bündnis 90/Die Grünen).

\subsection{The grant system}

The municipalities in Rhineland-Palatinate obtain two kinds of grants from the state-run fiscal equalization scheme: discretionary project grants and formula-based equalizing grants.

The discretionary and earmarked project grants (“Zweckzuweisungen”) include grants for urban renewal, investments in common welfare (investments that do not receive funding from any other grant program), culture, sport and tourism, schooling, rural renewal, infrastructure investments, industrial and commercial areas, and water and waste management. ${ }^{9}$ All types of municipalities (and also counties and associations of municipalities) are eligible to apply for project grants; some types of project grants, however, are directed only to individual types of municipalities. Table 1 describes the project grants in greater detail. Figure 1 shows the individual project grants as shares of the total volume of project grants for the years 2008-2011. The largest shares of total project grants come from grants for investments in common welfare (44.7 percent), rural renewal (22.4 percent), and infrastructure investments (13.1 percent). The state government has a strong discretionary power in distributing project grants. To receive a project grant, a municipality applies to the state ministry in charge. An administration office ("Aufsichts- und Dienstleistungsdirektion") headed until 2011 by a former state politician from the incumbent party - then considers the application in terms of the formal requirements, necessity, and economic efficiency of the project. The ministry finally decides on whether to approve the grant - in certain cases

\footnotetext{
${ }^{9}$ The municipalities also obtain other project grants that we do not include: grants for daycare facilities for children (the government does not have much discretionary power on distributing these grants) and grants for hospitals and grants for the state capital for investments in common welfare (data are not available).
} 
without consulting the administration office. Usually project grants are matching grants, making co-financing necessary for municipalities to obtain a grant.

The non-earmarked equalizing grants (“Schlüsselzuweisungen B2”) are formula-based and support municipalities with a fiscal need that exceeds their fiscal capacity. Six indicators determine the fiscal need: population density enters fiscal need negatively, whereas the other five indicators enter fiscal need positively: population, social security expenditure, number of pupils, number of stationing forces, and the municipality's function as a central place providing public goods for adjacent municipalities. The fiscal capacity consists of normalized tax revenues and includes a grant that guarantees a minimum level of fiscal capacity. ${ }^{10}$ The equalization system balances 50 percent of the difference between fiscal need and a weighted fiscal capacity (if positive; a detailed description is provided in the appendix). The state government is hardly able to manipulate the equalizing grants because detailed rules describe how grants are distributed. All types of municipalities and also counties receive equalizing grants. Small municipalities do not directly receive equalizing grants, as grants flow to associations of municipalities, which, however, have to pass them through to small municipalities that serve as a central place or have stationing forces. There are also other grants (that we do not include because they are numerically of minor importance): a per-capita lump-sum grant, formulabased grants for specific burdens such as the transport of school pupils, and a non-earmarked investment grant (the municipalities do not have to prove whether they use this investment grant - which is computed in the same way as equalizing grants - for investment purposes).

\footnotetext{
${ }^{10}$ Tax revenues include property taxes, the local business tax (both normalized with standardized tax rates), the share of the federal income tax, the share of the federal sales tax, and compensatory payments. See Bucovetsky and Smart (2006), Buettner (2006 and 2009), Buettner and Wildasin (2006), and Smart (2007) on how fiscal equalization grants influence tax policy and fiscal adjustment.
} 


\section{Empirical analysis}

\subsection{Data and descriptive statistics}

We use data on discretionary project grants for the years 2008-2011 compiled by the Ministry of the Interior, Sport, and Infrastructure Rhineland-Palatinate for the first time in 2012. ${ }^{11}$ Data on formula-based equalizing grants (2008-2011) and on other variables (2007-2010) come from the Statistical Office Rhineland-Palatinate. We use a time lag of one year between grants and explanatory variables because the distribution of grants generally depends on the fiscal variables of the previous year. We use election results from the state election administrator, which are available on the municipality level.

We exclude outliers from our analysis: 14 municipalities that had negative average project grants because they had to repay grants and four municipalities that had project grants of above 800 euros per capita. For one municipality with only 11 inhabitants the election results are not available due to election secrecy. The sample includes 2,287 municipalities. Table 2 presents the description of our variables. The descriptive statistics in Table 3 show that project grants per capita were 29.81 euros on average, whereas equalizing grants per capita were only 6.53 euros (the large discrepancy arises because we consider grants on the municipal level, while a large share of equalizing grants flows to counties and associations of municipalities that we do not consider in our analysis).

Figure 2 illustrates the second vote share of the incumbent SPD in the 2006 state election in the individual municipalities. There are heartlands of the SPD all over RhinelandPalatinate, except in the rural northwest of the state. Figure 3 shows quite some variation in the distribution of project grants per capita (2008-2011), but no distinct regional pattern. Figure 4 illustrates that equalizing grants per capita (2008-2011) were large in the northwest and the southwest of the state, and along the river Rhine.

\footnotetext{
${ }^{11}$ The ministry compiled the data in the course of discussing reform options of the fiscal equalization scheme (see Buettner et al. 2012).
} 
To arrive at first inferences about the nexus between incumbent vote share and grants we follow the approach of Boone et al. (2014, 404-407). The left part of Figure 5 shows the result of a non-parametric regression of discretionary project grants per capita on the vote share of the incumbent party, using kernel-weighted local polynomial smoothing; the right part shows a semi-parametric regression including all our (parametric) control variables. The increasing function in both panels suggests that the state government directed discretionary grants to core supporters (i.e., municipalities with a large vote share of the incumbent party). By contrast, there is no graphical evidence supporting the swing-voter model (i.e., that the closeness of an election as measured by the absolute difference between the SPD vote share and the vote share of the other main parties altogether mattered). In Figure 6 we turn to formula-based equalizing grants. The non-parametric regression in the left panel suggests that equalizing grants were distributed to municipalities where the vote share of the incumbent party was close to 50 percent (swing-voter model). The semi-parametric regression in the right panel including all our (parametric) control variables, however, does not show a humpshaped relationship between the incumbent vote share and equalizing grants per capita. In any event, there is no evidence that the government awarded equalizing grants to core supporters.

Because of the graphical evidence we proceed with testing empirically whether the state government awarded discretionary project grants to core supporters. We refer to the swing-voter model and to formula-based equalizing grants in sections 4.4 and 4.5.

\subsection{Empirical strategy}

We estimate our baseline model averaging the dependent variable (discretionary project grants) over the years 2008-2011 and all explanatory variables over the years 2007-2010 to account for the unsteady nature of grants and the lag structure in the distribution of grants (using a different lag would not affect the main explanatory variable, which is based on the 2006 state election). We do not estimate fixed-effects panel-data models because we are 
interested in the effect of the (time-invariant) variable describing the vote share of the incumbent party in the last election and thus cannot include fixed municipality effects. We refer to the results of random-effects panel-data models in the section on robustness tests. Since the dependent variable is left-censored, we estimate a Tobit model. The baseline regression model has the following form:

$$
\begin{aligned}
& \text { In Project } \text { grants }_{i}=\alpha+\beta \text { Vote share incumbent }{ }_{i}+\gamma \text { Incumbent representatives }_{i} \\
& +\delta \text { ln Fiscal capacity }+\Sigma_{j} \varepsilon_{j} \text { Fiscal need }_{i j} \\
& +\Sigma_{k} \zeta_{k} \text { Demographics }_{i k}+\eta \text { Share of unemployed } i+\Sigma_{l} \theta_{l} \text { Region }_{i l}+u_{i} \\
& \text { with } i=1, \ldots, 2287 ; j=1, \ldots, 9 ; k=1,2 ; l=1, \ldots, 4
\end{aligned}
$$

where the dependent variable Project grants $s_{i}$ describes the average project grants per capita (discretionary) in municipality $i$ over the years 2008-2011. ${ }^{12}$

We examine whether the incumbent state government awarded more grants to municipalities with many core supporters, proxied by the vote share of the incumbent state government. The variable Vote share incumbent $_{i}$ describes the second vote share of the incumbent SPD in percent (see section 3.2) in the state election 2006 in municipality $i$.

Politicians may influence how grants are distributed by other means than favoring core supporters (see section 2). It is conceivable that a home bias influences how grants are distri-

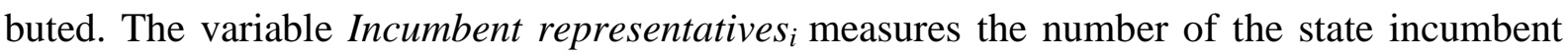
party's members of parliament born in municipality $i$ divided by the total population of that municipality (in percent; inferences regarding the vote share of the incumbent do not change when we refer to the electoral district where the individual politician was elected as "home"). We refer to the results of (i) testing the partisan alignment of the state and local level as

\footnotetext{
${ }^{12}$ Before taking the natural logarithm of Project grants $_{i}$ we add one euro to the variable to circumvent problems in taking the natural logarithm of zero (see, for example, Knight 2004). We do not have information about the number and quality of project-grant applications.
} 
measured by local council elections and the party affiliation of the mayor and (ii) testing the swing-voter model in the section on robustness tests. ${ }^{13}$

We include control variables based on the indicators that determine the fiscal capacity and fiscal need of a municipality in the fiscal equalization scheme. The variable Fiscal capacity $_{i}$ describes normalized tax revenues per capita and includes a grant that guarantees a minimum level of fiscal capacity (see section 3.4 and appendix). To describe fiscal need, we use six indicators that correspond to the indicators in the fiscal equalization scheme, and also include dummy variables for the different types of municipalities. Population $_{i}$ measures the

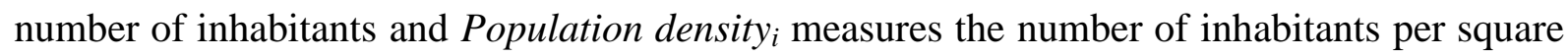
kilometer. Social expenditure $e_{i}$ is the social security expenditure per capita, which is only calculated for counties and county-independent cities (and zero otherwise). Share of pupils is the share of pupils in the total population (in percent), where pupils in regular schools are weighted with the factor 0.5 and pupils in special schools with the factor 1.5 . The number of pupils is not calculated for small municipalities (and thus zero). Stationing forces fis $_{i}$ the ratio of foreign stationing forces' relatives and non-barracked soldiers to the population (in percent). The state Rhineland-Palatinate designates municipalities as a central place when they function as a regional center providing public goods to adjacent municipalities. The variable Central place $_{i}$ describes the ratio of the weighted population of the region of a central place to the population of the central place (in percent; see appendix). Municipality $1_{i}$ is a dummy variable for small municipalities, Municipality $2_{i}$ for municipalities of intermediate size, and Municipality $3_{i}$ for large cities that are not county-independent (reference category: county-independent cities).

Other control variables that are likely to influence how grants are distributed are also included. We include two demographic control variables: Share of young population ${ }_{i}$ for the

\footnotetext{
${ }^{13}$ See Ade and Freier (2013) and Foremny et al. (2014) on the nexus between mayor elections and local council elections. Egger and Koethenbuerger (2012) examine whether local politicians that are party members differ in how they reward voters from local politicians that are not affiliated with a party.
} 
share of inhabitants under 18 (in percent) and Share of old population $_{i}$ for the share of inhabitants above 59 (in percent). The share of young population also serves as a proxy for the share of pupils, because the number of pupils used in the fiscal equalization scheme is not calculated for small municipalities. We include the variable Share of unemployed measuring the share of unemployed in the total population (in percent), because the actual social security expenditure used in the fiscal equalization scheme is calculated only for counties and countyindependent cities. Governments may direct grants disproportionately to individual regions. Region $_{i l}$ describes four dummy variables for the regions where the individual municipalities are located (East, West, Center, Palatinate; reference category: Rhine-Hesse). $u_{i}$ describes an error term. We estimate a Tobit model with standard errors robust to heteroskedasticity (Huber/White/sandwich standard errors - see Huber 1967 and White 1980; inferences do not change when we cluster standard errors on the level of the 163 associations of municipalities).

\subsection{Regression results}

Table 4 presents the marginal effects for the censored mean of our Tobit model with discretionary project grants per capita (2008-2011) as dependent variable. The first column shows the results when we include only the variable Vote share incumbent. In columns (2) and (3) we add control variables. In discussing the results, we focus on column (4), which is the estimate of our preferred specification that includes all control variables.

The marginal effect of Vote share incumbent attains statistical significance at the 1 percent level. The result indicates that project grants per capita increased by about 1.4 percent when the vote share of the state incumbent party increased by one percentage point. In other words, project grants per capita increased by about 14.9 percent when the vote share of the incumbent party increased by one standard deviation. The result thus suggests that project grants were awarded to core supporters of the state incumbent party. A municipality also received more project grants per capita the more state incumbent party members of parliament 
were born in the municipality (relative to the population), indicating a home bias; the effect of Incumbent representatives is statistically significant at the 1 percent level.

Municipalities with a large population received more project grants per capita than municipalities with a small population. The marginal effect of Population is statistically significant at the 1 percent level. The numerical meaning of the effect is that when the population increased by one percent, project grants per capita increased by 0.6 percent. When the variable Population density increased by one percent, project grants per capita decreased by 0.2 percent (statistically significant at the 10 percent level). Municipalities with high social expenditure per capita received more project grants per capita (significant at the 5 percent level). Central places also obtained more project grants per capita; the marginal effect of the variable Central place attains statistical significance at the 1 percent level. A municipality thus obtained the more transfers the more people in the surrounding area benefit from the municipality's expenditures. Small municipalities (Municipality 1), municipalities of intermediate size (Municipality 2), and large cities that are not county-independent (Municipality 3) received notably more project grants per capita than county-independent cities (significant at the 5 percent level), which is indeed intended by the legislator as large cities obtain more formula-based grants. Combined with the effect of increasing project grants per capita when the population increases, the effects of the dummy variables describing the types of municipalities purport that project grants per capita decreased with the next-larger types of municipalities, but that project grants per capita increased in the population within every type of municipality. Municipalities in the region Palatinate received more project grants per capita than municipalities in the region Rhine-Hesse (reference category). The effects of the variables Share of pupils, Stationing forces, Share of young population, Share of old population, Share of unemployed, Region East, Region West, and Region Center do not turn out to be statistically significant in any specification. In particular, Fiscal capacity lacks statistical significance. From a distributional perspective, we would have expected a negative 
effect of the fiscal capacity on project grants per capita. The expected negative effect may however be counteracted by the circumstance that municipalities have to co-finance projects in many cases (see section 3.4), which seems difficult for indigent municipalities. In any event, fiscal capacity lacking statistical significance casts doubt on whether the allocation of discretionary project grants is suitable.

\subsection{Robustness tests}

We submitted our results to rigorous robustness tests using different specifications of our regressions and different samples. None of these robustness tests indicates any severe fragility of our results. For the individual robustness tests, Table 5 presents the marginal effects based on the specification with all control variables (column 4 in Table 4).

In our baseline model we used a Tobit estimator, taking the left-censored nature of the dependent variable into account. Inferences do not change when we estimate OLS or negative binomial models. We also employed panel-data models. Since we are interested in the effect of the time-invariant variable Vote share incumbent, we can only run a random-effects model. Independent of whether we include fixed year effects or not, the results confirm that project grants per capita were higher in municipalities with a large vote share of the state incumbent party.

We have replaced the dependent variable Project grants by the individual grant programs (see Table 1). Using Investments in common welfare and Rural renewal as dependent variables, which describe the largest areas eligible for funding (see Figure 1), the marginal effect of Vote share incumbent is positive and attains statistical significance. Using the other grant programs as dependent variables, the coefficient of Vote share incumbent does not turn out to be statistically significant. These grant programs are typically very small, both in volume and in the number of municipalities receiving grants. 
It is conceivable that the state government awarded grants to core-supporter municipalities in particular before the state election. ${ }^{14}$ We tested for electoral cycles by interacting the incumbent vote share with the individual year dummies. The results do however not show that transfers to core-supporter municipalities were higher in the election year than in other years.

The four types of municipalities in Rhineland-Palatinate differ in their extent of policy autonomy. Inferences do not change when we only estimate the model for small municipalities (Municipality 1). Estimating the model for the other types of municipalities alone is not meaningful because sample sizes are too small.

Politicians may well influence the distribution of grants to reward their fellow party members (party-alignment model). We tested whether inferences change when we use the SPD vote share in the local council elections, instead of the SPD vote share in the state election, as an explanatory variable. The results do not show that state politicians awarded more grants per capita to municipalities with a large SPD vote share in the local council elections. When we include the SPD vote share in the state election and the SPD vote share in the local council elections in one specification, the results corroborate that project grants per capita were higher in municipalities where the SPD had a large vote share in the state election, but not in municipalities where the SPD had a large vote share in the local council elections.

We also included a dummy variable Mayor that assumes the value one if the mayor of a municipality is from the state incumbent party. Data on the party affiliation of the mayor is, however, not available for many small municipalities. When we include the mayor variable the number of observations thus goes down to 1265 . The coefficient of the mayor variable lacks statistical significance, independent of whether we include the SPD vote share in the

\footnotetext{
${ }^{14}$ On electoral cycles in the German states and municipalities, see, e.g., Tepe and Vanhuysse (2009, 2013, and 2014), Mechtel and Potrafke (2013), Foremny and Riedel (2014), Garmann (in press), Kauder et al. (2016a and 2016b), and Riem (2016a and 2016b).
} 
state election or not. The results still show that project grants per capita were higher in municipalities with many core supporters of the state incumbent.

We replaced the vote share of the SPD by the vote shares of the CDU, the FDP or the Greens. This robustness test does not give rise to any concern either: project grants per capita decreased when the CDU's vote share increased, whereas the effects of the vote shares of the FDP and the Greens do not turn out to be statistically significant.

We tested whether project grants per capita were also higher in swing municipalities. The regressions in Table 6 using the absolute difference between the SPD vote share and the vote share of the other main parties altogether (CDU, FDP, and Greens) as the main explanatory variable corroborate the graphical evidence from Figure 5 and do not show that project grants per capita were higher in municipalities with many swing voters. This result is robust to using different regression techniques, and also to considering only small municipalities or local council elections. Testing the swing-voter model with the closeness of an election instead of the number of swing voters relies on the assumption of a symmetric and single-peaked distribution of preferences (see section 2). If, however, preferences are skewed to the right, which is likely the case in Rhineland-Palatinate, the number of swing voters is highest where the incumbent SPD is somewhat weaker than the other main parties altogether. The results do however not show that grants were directed to municipalities where the SPD obtained 5 or 10 percentage points fewer votes than the other main parties. We do thus still not find evidence for the swing-voter model.

\subsection{Formula-based equalizing grants}

In emerging and developing countries, politicians have been shown to manipulate formulabased grants (see, e.g., Litschig 2012 and Banful 2011). We are convinced that formula-based grants are not manipulated in Germany; the graphical evidence in Figure 6, however, requires elaborating further on these grants. Two ways of manipulating formula-based equalizing 
grants spring to mind. Firstly, the state government may manipulate grants by not applying the formula correctly. The horizontal line in the right panel of Figure 6 already indicates that grants are not manipulated, at least not according to municipalities' political preferences: the semi-parametric regression accounts for the components of the formula that is applied to calculate the grants, and there is no correlation between the vote share of the incumbent party and equalizing grants per capita. Also the regressions in the upper part of Table 7 do not show that municipalities' political preferences influenced the level of equalizing grants per capita (the small and marginally significant effect for the swing-voter model notwithstanding).

Secondly, it is conceivable that the formula for equalizing grants was designed such that individual municipalities benefit. The left panel of Figure 6 and the results in the lower part of Table 7 - both not controlling for the components of the formula - indeed indicate that municipalities with many swing voters (but not municipalities with many core supporters) obtained higher equalizing grants per capita. We do not, however, interpret this as evidence for some government to have manipulated the formula in order to woo swing voters. We rather advance a different argument for why municipalities received higher grants per capita where elections were close. In cities, elections are often close, whereas in smaller municipalities landslide victories for individual parties are quite common. Cities, however, also obtain larger per-capita grants, e.g. because they serve as central places providing public goods for adjacent municipalities. Larger grants for cities are also justified to compensate for congestion externalities, because the empirical literature shows that cities have a higher level of productivity compared to the countryside (see, e.g., Sveikauskas 1975). Comparing Rhineland-Palatinate to other states, we also do not see an indication of cities to be overemphasized in the formula. The hump-shaped relationship indeed vanishes when excluding central places from Figure 6 (not shown). We do therefore not interpret the higher level of equalizing grants in municipalities with close elections as a causal effect. 


\section{Conclusion}

We investigate whether politicians award intergovernmental grants to core supporters. Our new dataset contains information on discretionary project grants from a German state government to municipalities over the period 2008-2011. The results show that discretionary grants were awarded to municipalities with many core supporters of the incumbent state government. Grants per capita increased by about 1.4 percent when the vote share of the incumbent party in the state election increased by one percentage point. A municipality's fiscal capacity did not help to predict the level of discretionary grants. The vote share of the incumbent party being statistically significant, while the fiscal capacity is not, casts doubt on how suitable the allocation of grants actually is. The results do not show that politicians manipulated formula-based grants.

The incumbent party in Rhineland-Palatinate may have manipulated the grant distribution to reward their core supporters, corroborating the core-supporter hypothesis advanced by Cox and McCubbins (1986). The government did not publish any information on grant distribution for many years. Lax disclosure requirements may have served as a gateway to manipulating grants. It is, however, also conceivable that municipalities with a population that espouses social-democratic attitudes applied for more eligible projects than other municipalities (including projects more in line with the political preferences of the state government) or were more adamant in applying for project grants in the first place. When deciding about whether to apply for a grant, a municipality may anticipate the state government's decision. Grant applications from a municipality with many voters of the state incumbent party should thus be more likely the more the municipality expects the state government to manipulate the grant distribution in the interest of these municipalities. Given a disproportionately large number of grant applications from core-supporter municipalities, grants may well be expected to flow to these municipalities - even without the state government manipulating the grant distribution. 
Because our dataset contains information on the discretionary project grants only over the period 2008-2011, and there is no data on previous years available, we cannot rule out that grants were directed to those areas where the incumbent party enjoyed the most political support. These areas could be so supportive of the incumbent government because of a history of favorable grant treatment. To be sure, this issue confines inferences to be drawn based on our study and prevented us from deriving causal effects.

In any event, we propose to trim discretionary project grants to the benefit of formulabased grants. Discretionary project grants are justified for only two reasons: (i) the state government is better informed about local preferences than local governments or faces stronger incentives to satisfy these preferences; (ii) local public goods and services exert spillover effects to future periods (investments) or to other municipalities, which are not internalized by local politicians that are myopic or not interested in the well-being of other jurisdictions. For most discretionary project grants, neither of these reasons applies: local politicians are in close contact with citizens and are thus, in most cases, better informed of local needs than state politicians; there is also no case for believing that state politicians cater to voters' preferences more than local politicians do, as voters may impose sanctions on politicians at both levels of government by voting for alternative candidates/parties. Spill-over effects of local public goods or services may, in some cases, support discretionary project grants at first sight; well-aligned grants are, however, hard to calculate as quantifying spillover effects is a most difficult task, a reasoning that applies for both spill-over effects benefitting other municipalities and spill-over effects benefitting the municipality in question in the future. To some extent the fiscal equalization scheme already incorporates spill-over effects accruing to other municipalities by acknowledging a municipality's function as a central place. When the benefits of public goods spill over to future periods, general grants with an obligation to invest some share may be a better choice than project grants. In any event, one needs to trade off potential advantages against the drawbacks of discretionary 
project grants, which include - compared to formula-based grants - reduced municipal autonomy, less transparency, more bureaucratic government, and, finally, incentives for manipulations based on political color. 


\section{Acknowledgements}

We would like to thank Elias Braunfels, Marta Curto-Grau, Joshua C. Hall, Thorsten Martin, Adam Millsap, Cecilia Rumi, Albert Solé-Ollé, Thomas Stratmann, and seminar/conference participants at the Public Choice Society (Charleston 2014 and Fort Lauderdale 2016), European Public Choice Society (Cambridge 2014), International Institute of Public Finance (Lugano 2014), CESifo Public Sector Economics Conference (Munich 2015), European Association of Law and Economics (Vienna 2015), CESifo Norwegian-German Seminar on Public Economics (Munich 2015), Australasian Public Choice Conference (Brisbane 2015), and Verein für Socialpolitik (Augsburg 2016) for their helpful comments. Adam Job, Danny Kurban, Michael Lebacher, Jakob Müller, Thaddäus Pollmächer, and Leonard Thielmann provided excellent research assistance. 


\section{References}

Ade, F. and R. Freier (2013). Divided government versus incumbency externality effect quasi-experimental evidence on multiple voting decisions, European Economic Review 64, 1-20.

Aidt, T. and C. Rauh (2015). The Big Five personality traits and partisanship in England: Who are the core and swing voters? Unpublished paper.

Albouy, D. (2013). Partisan representation in congress and the geographic distribution of federal funds, Review of Economics and Statistics 95, 127-141.

Anderson, G.M. and R.D. Tollison (1991). Congressional influence and patterns of New Deal spending 1933-1939, Journal of Law \& Economics 34, 161-175.

Ansolabehere, S., A. Gerber and J. Snyder (2002). Equal votes, equal money: Court-ordered redistricting in public expenditures in the American states, American Political Science Review 96, 767-777.

Ansolabehere, S. and J.M. Snyder, Jr. (2006). Party control of state government and the distribution of public expenditures, Scandinavian Journal of Economics 108, 547-569.

Arulampalam, W., S. Dasgupta and A. Dhillon (2009). Electoral goals and center-state transfers: A theoretical model and empirical evidence from India, Journal of Development Economics 88, 103-119.

Atlas, C.M., T.W. Gilligan, R.J. Hendershott and M.A. Zupan (1995). Slicing the federal government net spending pie: Who wins, who loses, and why, American Economic Review 85, 624-629.

Banful, A.B. (2011). Do formula-based intergovernmental transfer mechanisms eliminate politically motivated targeting? Evidence from Ghana, Journal of Development Economics 96, 380-390.

Boone, C., A. Dube and E. Kaplan (2014). The political economy of discretionary spending: Evidence from the American Recovery and Reinvestment Act, Brookings Papers on Economic Activity, Spring 2014, 375-441.

Borck, R. and S. Owings (2003). The political economy of intergovernmental grants, Regional Science and Urban Economics 33, 139-156.

Bracco, E., B. Lockwood, M. Redoano and F. Porcelli (2015). Intergovernmental grants as signals and the alignment effect: Theory and evidence, Journal of Public Economics 123, 78-91.

Brollo, F. and T. Nannicini (2012). Tying your enemy's hands in close races: The politics of federal transfers in Brazil, American Political Science Review 106, 742-761.

Bucovetsky, S. and M. Smart (2006). The efficiency consequences of local revenue equalization: Tax competition and tax distortions, Journal of Public Economic Theory $8,119-144$.

Buettner, T. (2006). The incentive effect of fiscal equalization transfers on tax policy, Journal of Public Economics 90, 477-497. 
Buettner, T. (2009). The contribution of equalization transfers to fiscal adjustment: Empirical results for German municipalities and a US-German comparison, Journal of Comparative Economics 37, 417-431.

Buettner, T., A. Ebertz, B. Kauder and M. Reischmann (2012). Finanzwissenschaftliche Begutachtung des kommunalen Finanzausgleichs in Rheinland-Pfalz, ifo Forschungsberichte 58, Ifo Institute, Munich.

Buettner, T. and F. Holm-Hadulla (2013). City size and the demand for local public goods, Regional Science and Urban Economics 43, 16-21.

Buettner, T. and D.E. Wildasin (2006). The dynamics of municipal fiscal adjustment, Journal of Public Economics 90, 1115-1132.

Cadot, O., L.-H. Röller and A. Stephan (2006). Contribution to productivity or pork barrel? The two faces of infrastructure investment, Journal of Public Economics 90, 11331153.

Carozzi, F. and L. Repetto (2016). Sending the pork home: Birth town bias in transfers to Italian municipalities, Journal of Public Economics 134, 42-52.

Case, A. (2001). Election goals and income redistribution: Recent evidence from Albania, European Economic Review 45, 405-423.

Castells, A. and A. Solé-Ollé (2005). The regional allocation of infrastructure investment: The role of equity, efficiency and political factors, European Economic Review 49, 1185 1205 .

Chen, J. (2010). The effect of electoral geography on pork barreling in bicameral legislatures, American Journal of Political Science 54, 301-322.

Cox, G.W. and M.D. McCubbins (1986). Electoral politics as a redistributive game, Journal of Politics 48, 370-389.

Curto-Grau, M., A. Herranz-Loncán and A. Solé-Ollé (2012). Pork-barrel politics in semidemocracies: The Spanish "parliamentary roads," 1880-1914, Journal of Economic History 72, 771-796.

Curto-Grau, M., A. Solé-Ollé and P. Sorribas-Navarro (2014). Does electoral competition curb party favoritism? Unpublished paper.

Dahlberg, M. and E. Johansson (2002). On the vote-purchasing behavior of incumbent governments, American Political Science Review 96, 27-47.

Dalle Nogare, C. and B. Kauder (2016). Term limits for mayors and intergovernmental grants: Evidence from Italian cities, unpublished paper.

Dixit, A. and J. Londregan (1996). The determinants of success of special interests in redistributive politics, Journal of Politics 58, 1132-1155.

Dixit, A. and J. Londregan (1998). Ideology, tactics, and efficiency in redistributive politics, Quarterly Journal of Economics 113, 497-529.

Egger, P. and M. Koethenbuerger (2012). Do political parties curb pork-barrel spending? Municipality-level evidence from Germany, unpublished paper.

Feld, L.P. and C.A. Schaltegger (2005). Voters as a hard budget constraint: On the determination of intergovernmental grants, Public Choice 123, 147-169. 
Fiva, J.H. and A.H. Halse (in press). Local favoritism in at-large proportional representation systems, Journal of Public Economics.

Foremny, D., R. Freier, M.-D. Moessinger and M. Yeter (2014). Overlapping political budget cycles in the legislative and the executive, ZEW Discussion Paper 14-099.

Foremny, D. and N. Riedel (2014). Business taxes and the electoral cycle, Journal of Public Economics 115, 48-61.

Garmann, S. (in press). Electoral cycles in public administration decisions: Evidence from German municipalities, Regional Studies.

Geys, B. and J. Vermeir (2014). Party cues in elections under multilevel governance: Theory and evidence from US states, Journal of the European Economic Association 12, 1029 1058 .

Gist, J.R. and R.C. Hill (1984). Political and economic influences on the bureaucratic allocation of federal funds: The case of urban development action grants, Journal of Urban Economics 16, 158-172.

Grossman, P.J. (1994). A political theory of intergovernmental grants, Public Choice 78, 295 303.

Helland, L. and R.J. Sørensen (2009). Geographical redistribution with disproportional representation: A politico-economic model of Norwegian road projects, Public Choice 139, 5-19.

Hodler, R. and P.A. Raschky (2014). Regional favoritism, Quarterly Journal of Economics 129, 995-1033.

Horiuchi, Y. and J. Saito (2003). Reapportionment and redistribution: Consequences of electoral reform in Japan, American Journal of Political Science 47, 669-682.

Huber, P.J. (1967). The behavior of maximum likelihood estimates under nonstandard conditions, Proceedings of the Fifth Berkeley Symposium on Mathematical Statistics and Probability, 221-233.

Jennes, G. and D. Persyn (2015). The effect of political representation on the geographic distribution of income: Evidence using Belgian data, European Journal of Political Economy 37, 178-194.

Joanis, M. (2011). The road to power: Partisan loyalty and the centralized provision of local infrastructure, Public Choice 146, 117-143.

Johansson, E. (2003). Intergovernmental grants as a tactical instrument: Empirical evidence from Swedish municipalities, Journal of Public Economics 87, 883-915.

Kauder, B., M. Krause and N. Potrafke (2016a). Electoral cycles in MP's salaries: Evidence from the German states, CESifo Working Paper No. 6028.

Kauder, B., N. Potrafke and C. Schinke (2016b). Manipulating fiscal forecasts: Evidence from the German states, unpublished paper.

Kemmerling, A. and A. Stephan (2002). The contribution of local public infrastructure to private productivity and its political economy: Evidence from a panel of large German cities, Public Choice 113, 403-424. 
Knight, B. (2002). Endogenous federal grants and crowd-out of state government spending: Theory and evidence from the Federal Highway Aid Program, American Economic Review 92, 71-92.

Knight, B. (2004). Parochial interests and the centralized provision of local public goods: Evidence from congressional voting on transportation projects, Journal of Public Economics 88, 845-866.

Knight, B. (2008). Legislative representation, bargaining power and the distribution of federal funds: Evidence from the US congress, Economic Journal 118, 1785-1803.

Kriner, D.L. and A. Reeves (2015). Presidential particularism and divide-the-dollar politics, American Political Science Review 109, 155-171.

Levitt, S.D. and J.M. Snyder, Jr. (1995). Political parties and the distribution of federal outlays, American Journal of Political Science 39, 958-980.

Lindbeck, A. and J.W. Weibull (1987). Balanced-budget redistribution as the outcome of political competition, Public Choice 52, 273-297.

Lindbeck, A. and J.W. Weibull (1993). A model of political equilibrium in a representative democracy, Journal of Public Economics 51, 195-209.

Litschig, S. (2012). Are rules-based government programs shielded from special-interest politics? Evidence from revenue-sharing transfers in Brazil, Journal of Public Economics 96, 1047-1060.

Maaser, N. and T. Stratmann (2014). Distributional consequences of political representation, unpublished paper.

Martin, P.S. (2003). Voting's rewards: Voter turnout, attentive publics, and congressional allocation of federal money, American Journal of Political Science 47, 110-127.

Mechtel, M. and N. Potrafke (2013). Electoral cycles in active labour market policies, Public Choice 156, 181-194.

Rechnungshof Rheinland-Pfalz (2011). Jahresbericht 2011.

Riem, M. (2016a). Corporate investment decisions under political uncertainty, unpublished paper.

Riem, M. (2016b). Does political uncertainty influence firm owners' business perceptions? Unpublished paper.

Sengupta, B. (2011). Provision of public goods in a federal economy: The role of party politics, European Journal of Political Economy 27, 104-119.

Sjahrir, B.S., G.J. Gonschorek and G.G. Schulze (2015). The political economy of centralgovernment transfers: Empirical evidence from Indonesia, unpublished paper.

Smart, M. (2007). Raising taxes through equalization, Canadian Journal of Economics 40, $1188-1212$.

Solé-Ollé, A. (2013). Inter-regional redistribution through infrastructure investment: Tactical or programmatic? Public Choice 156, 229-252.

Solé-Ollé, A. and P. Sorribas-Navarro (2008). The effects of partisan alignment on the allocation of intergovernmental transfers. Difference-in-differences estimates for Spain, Journal of Public Economics 92, 2302-2319. 
Stratmann, T. (1996). How reelection constituencies matter: Evidence from political action committees' contributions and congressional voting, Journal of Law \& Economics 39, 603-635.

Stratmann, T. and M. Baur (2002). Plurality rule, proportional representation, and the German Bundestag: How incentives to pork-barrel differ across electoral systems, American Journal of Political Science 46, 506-514.

Stratmann, T. and J. Wojnilower (2015). Presidential particularism: Distributing funds between alternative objectives and strategies, Mercatus Working Paper.

Sveikauskas, L. (1975). The productivity of cities, Quarterly Journal of Economics 89, 393413.

Tepe, M. and P. Vanhuysse (2009). Educational business cycles, Public Choice 139, 61-82.

Tepe, M. and P. Vanhuysse (2013). Cops for hire? The political economy of police employment in the German states, Journal of Public Policy 33, 165-199.

Tepe, M. and P. Vanhuysse (2014). A vote at the opera? The political economy of public theatres and orchestras in the German states, European Journal of Political Economy 36, 254-273.

Veiga, L.G. and M.M. Pinho (2007). The political economy of intergovernmental grants: Evidence from a maturing democracy, Public Choice 133, 457-477.

Vicente, P.C. (2014). Is vote buying effective? Evidence from a field experiment in West Africa, Economic Journal 124, F356-F387.

Weingast, B.R., K.A. Shepsle and C. Johnsen (1981). The political economy of benefits and costs: A neoclassical approach to distributive politics, Journal of Political Economy 89, 642-664.

White, H. (1980). A heteroskedasticity-consistent covariance matrix estimator and a direct test for heteroskedasticity, Econometrica 48, 817-838.

Worthington, A.C. and B.E. Dollery (1998). The political determination of intergovernmental grants in Australia, Public Choice 94, 299-315.

Wright, G. (1974). The political economy of New Deal spending: An econometric analysis, Review of Economics and Statistics 56, 30-38. 
Figure 1: Shares of discretionary project grants, 2008-2011

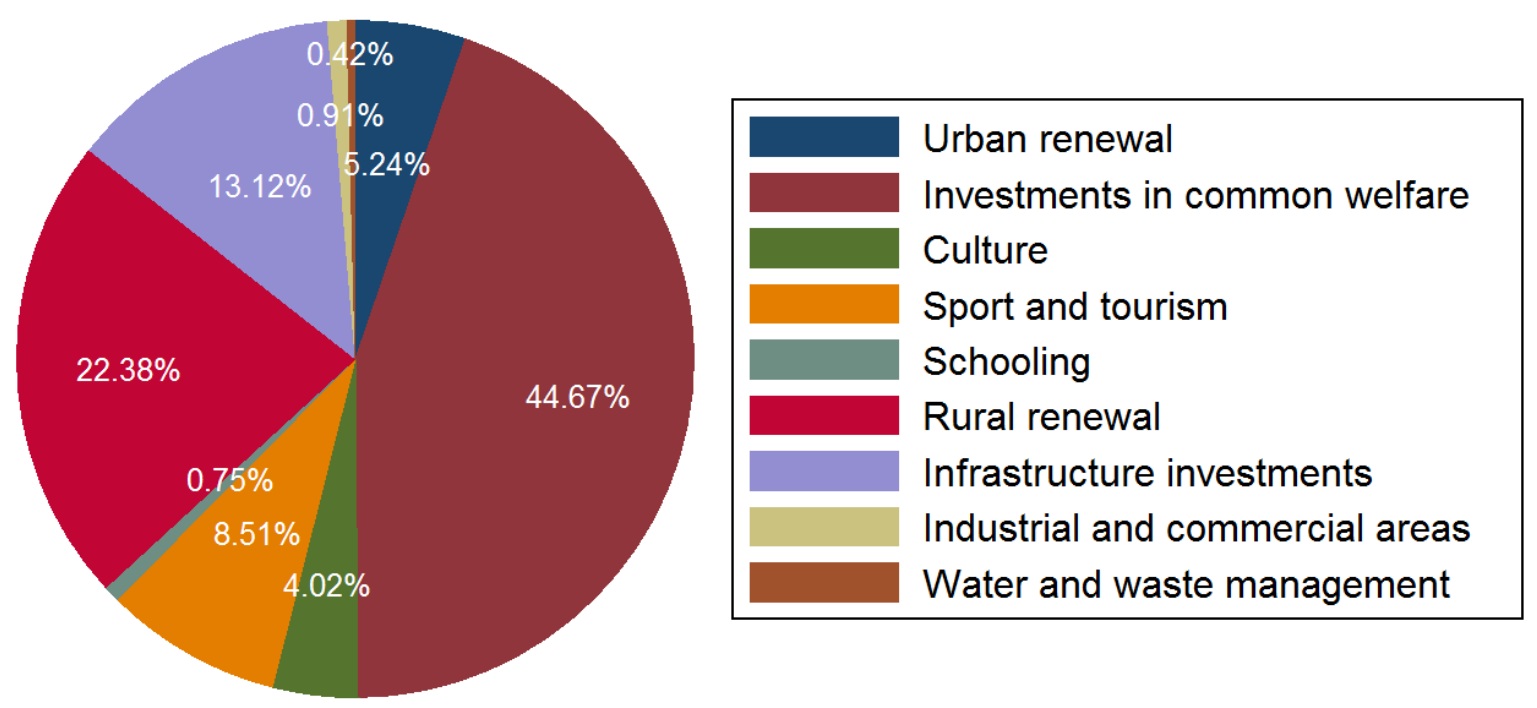

Source: Statistical Office Rhineland-Palatinate, own illustration. 
Figure 2: Vote share of the incumbent SPD in the 2006 state election (in percent)
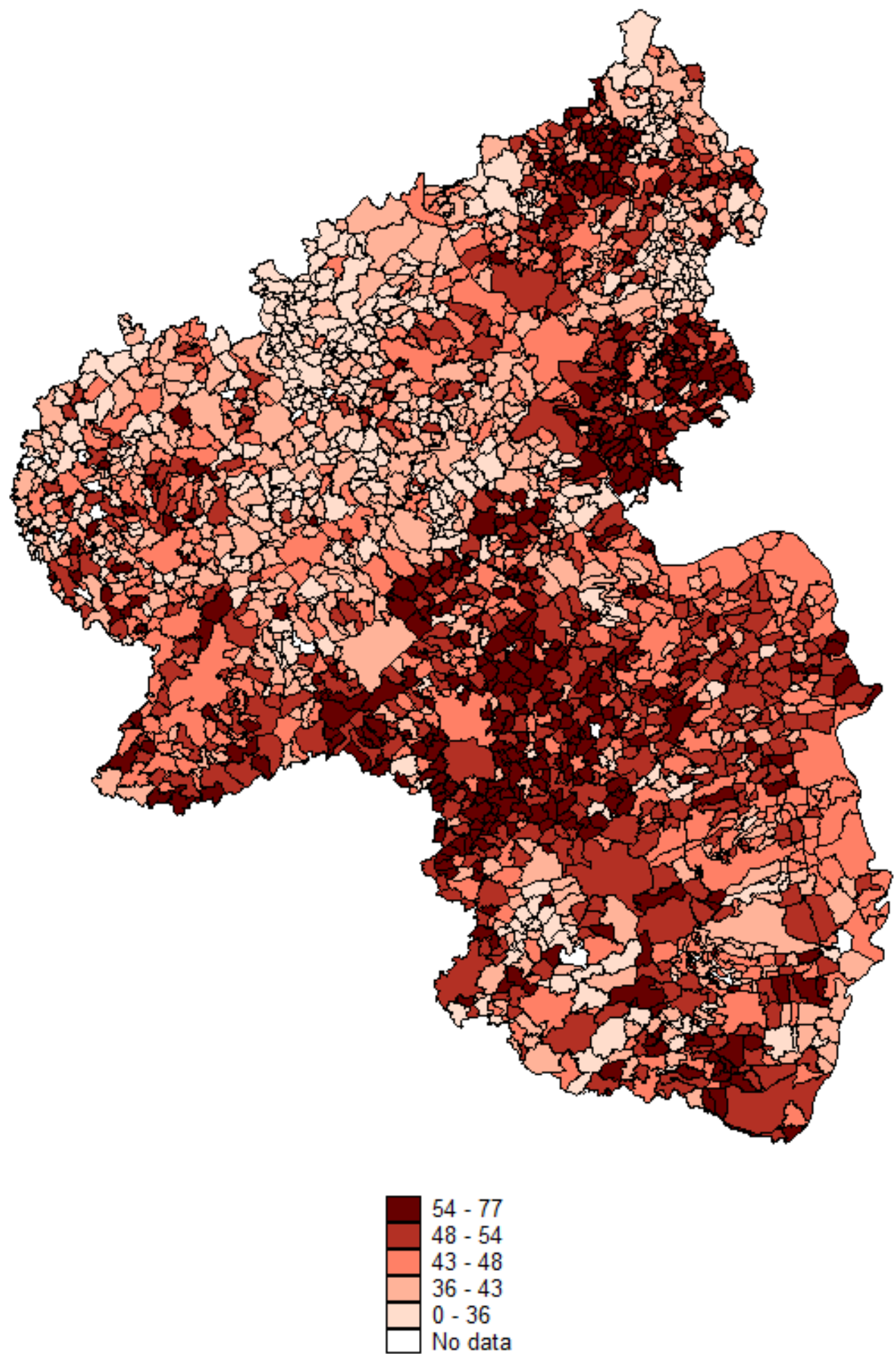

Source: State election administrator, Statistical Office Rhineland-Palatinate, own illustration. 
Figure 3: Regional distribution of discretionary project grants (per capita), 2008-2011

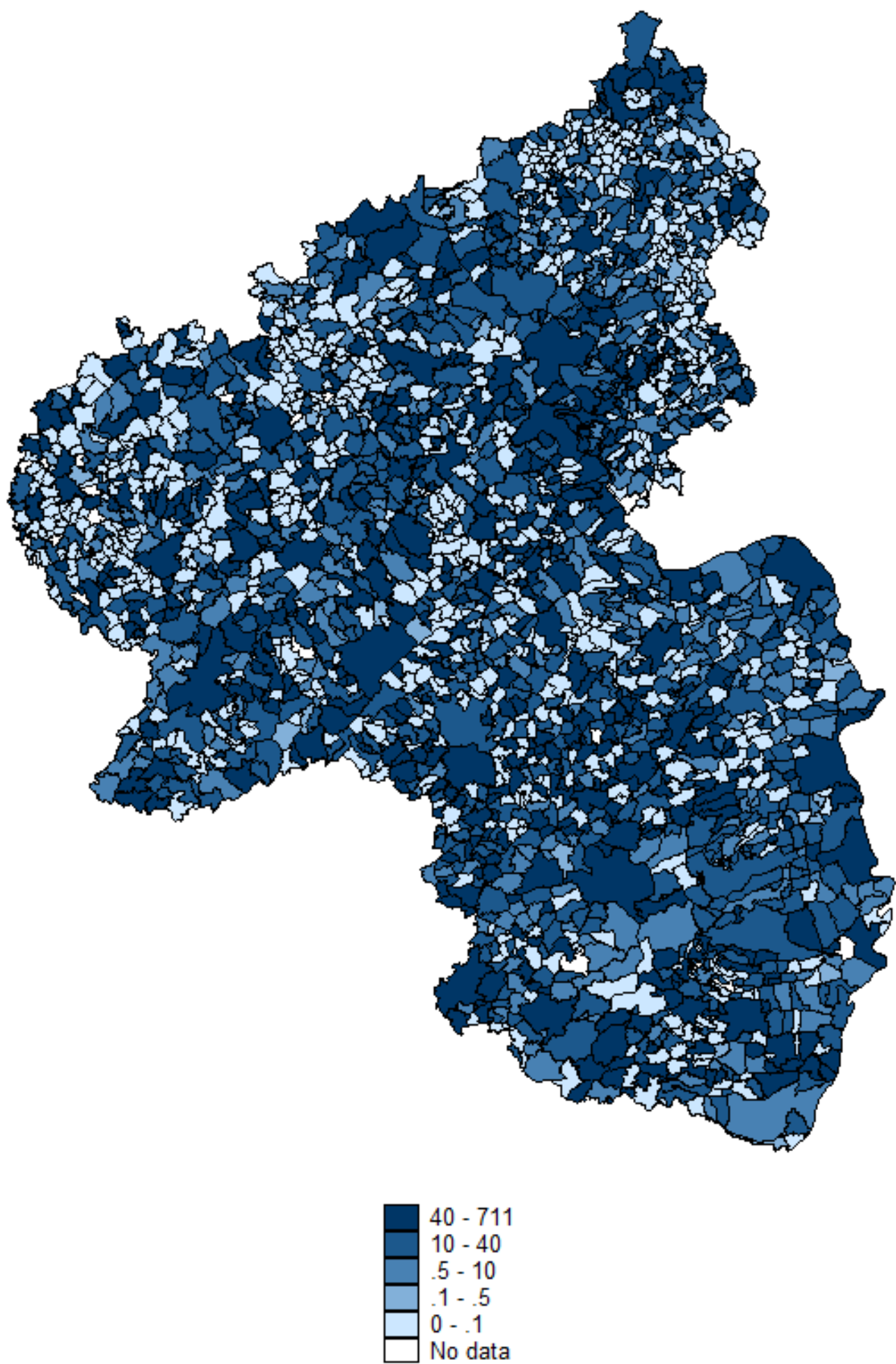

Grants measured in euros. Source: Ministry of the Interior, Sport, and Infrastructure Rhineland-Palatinate, own illustration. 
Figure 4: Regional distribution of formula-based equalizing grants (per capita), 2008-2011

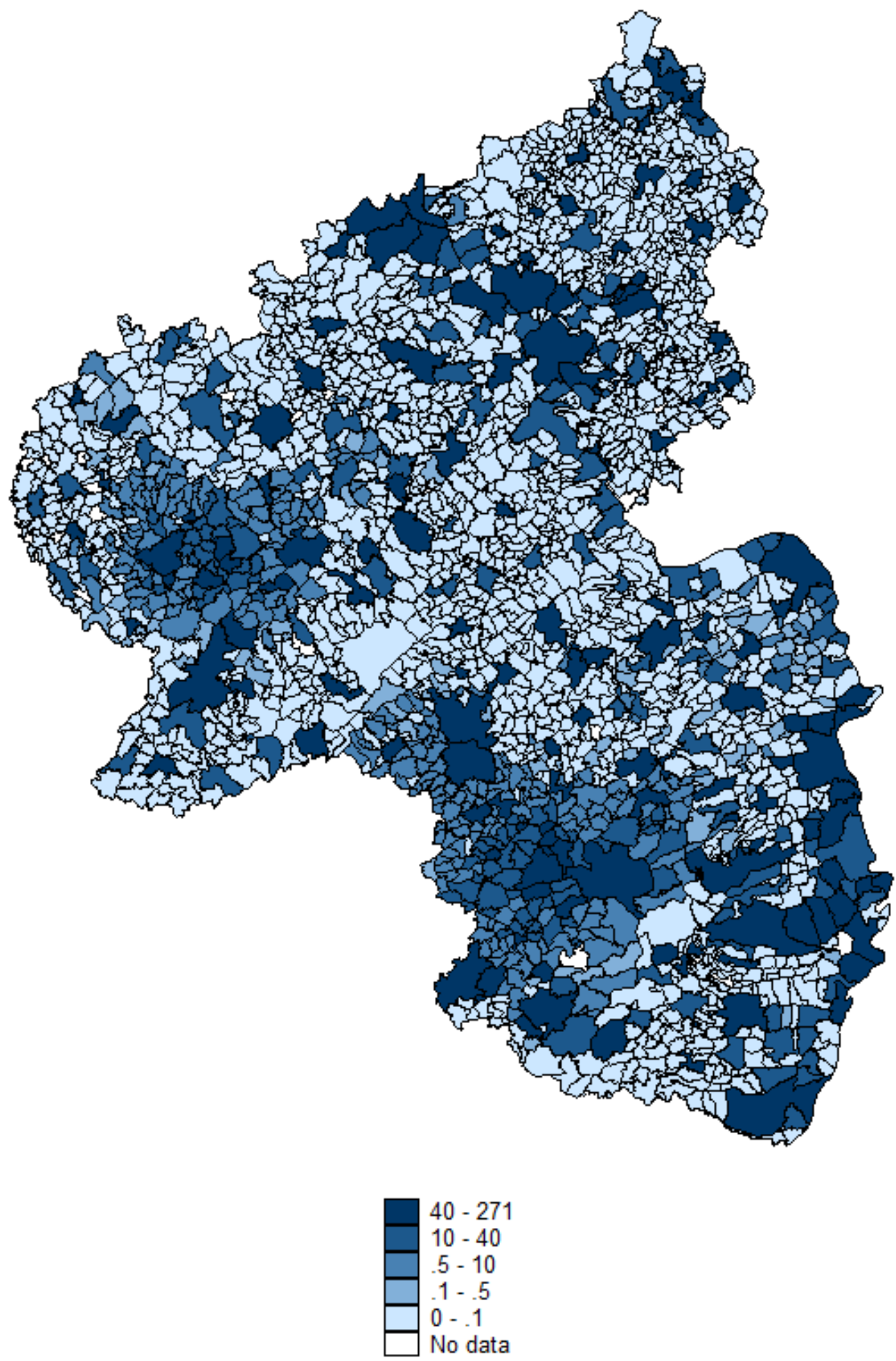

Grants measured in euros. Source: Statistical Office Rhineland-Palatinate, own illustration. 
Figure 5: Discretionary project grants 2008-2011 (per capita) and vote share of the incumbent SPD in the 2006 state election (in percent) - non-parametric regressions (no control variables) and semi-parametric regressions (including control variables)

(a) Non-parametric

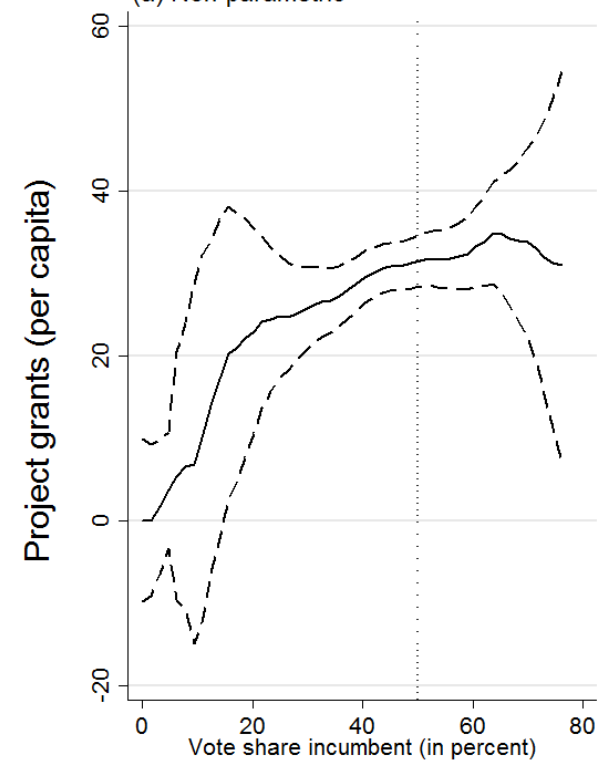

(b) Semi-parametric

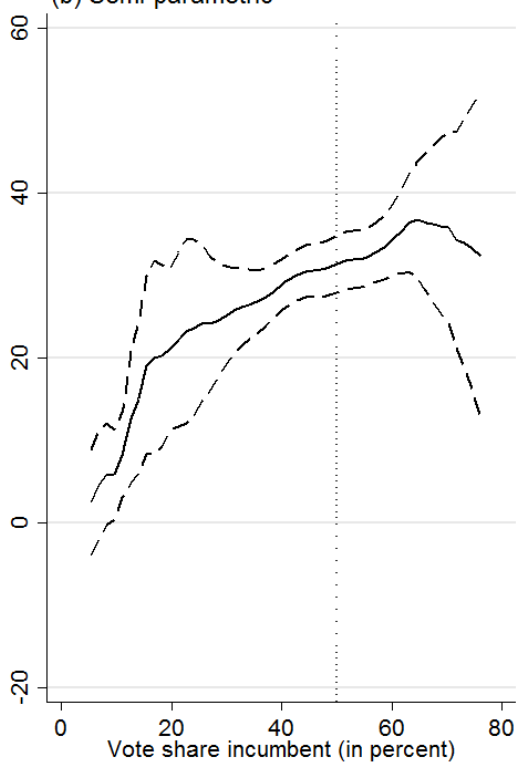

Grants measured in euros. Dashed lines describe 5 percent confidence intervals (standard errors are bootstrapped with 100 replications). The weighted local polynomial estimates are calculated with the Epanechnikov kernel function with a rule-of-thumb bandwidth estimator. The parametric components are differenced out using the Yatchew method. Source: State election administrator, Ministry of the Interior, Sport, and Infrastructure Rhineland-Palatinate, own illustration.

Figure 6: Formula-based equalizing grants 2008-2011 (per capita) and vote share of the incumbent SPD in the 2006 state election (in percent) - non-parametric regressions (no control variables) and semi-parametric regressions (including control variables)

(a) Non-parametric

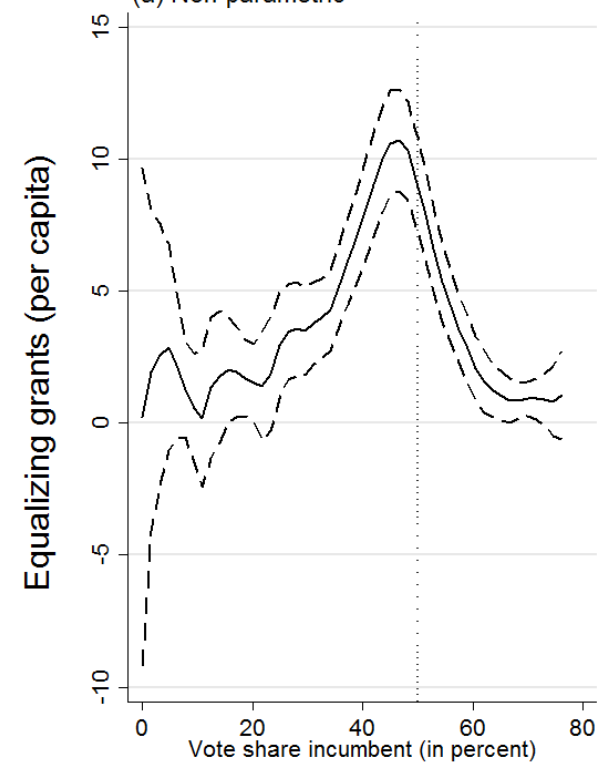

(b) Semi-parametric

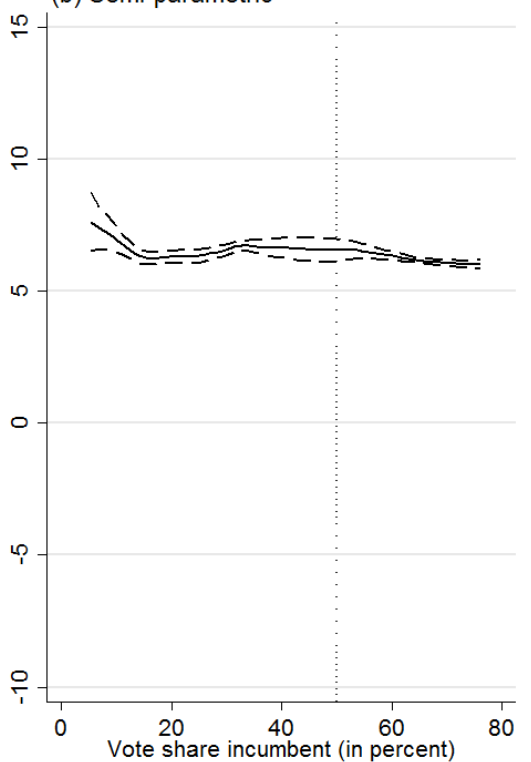

Grants measured in euros. Dashed lines describe 5 percent confidence intervals (standard errors are bootstrapped with 100 replications). The weighted local polynomial estimates are calculated with the Epanechnikov kernel function with a rule-of-thumb bandwidth estimator. The parametric components are differenced out using the Yatchew method. Source: State election administrator, Statistical Office Rhineland-Palatinate, own illustration. 
Table 1: Description of project grants

\begin{tabular}{|c|c|}
\hline Areas eligible for funding & Description \\
\hline Urban renewal & Urban renewal \\
\hline Investments in common welfare & $\begin{array}{l}\text { Investments in common welfare that do not receive } \\
\text { funding from any other grant program }\end{array}$ \\
\hline Culture & $\begin{array}{l}\text { Theaters, orchestras, culture projects, conservatories, } \\
\text { libraries, museums, cultural monuments }\end{array}$ \\
\hline Sport and tourism & Sport, leisure and tourism facilities; health resorts \\
\hline Schooling & School building and initial equipment \\
\hline Rural renewal & Rural renewal \\
\hline Infrastructure investments & $\begin{array}{l}\text { Construction, reconstruction, and renovation of streets, } \\
\text { bridges, parking areas, and rail tracks; public transport }\end{array}$ \\
\hline Industrial and commercial areas & $\begin{array}{l}\text { Development and renovation of industrial and commercial } \\
\text { areas }\end{array}$ \\
\hline Water and waste management & $\begin{array}{l}\text { Water supply and distribution, waste management, } \\
\text { electricity industry, energy efficiency, energy supply, } \\
\text { soil protection }\end{array}$ \\
\hline
\end{tabular}

No discretionary power or no data available

Daycare facilities for children Personnel costs of daycare facilities for children

Hospitals

Hospitals

Investments in common welfare Investments in common welfare (state capital) (state capital)

Composition according to §18 Landesfinanzausgleichsgesetz Rheinland-Pfalz. 
Table 2: Description of variables

\begin{tabular}{|c|c|}
\hline Variable & Description \\
\hline Project grants & Project grants (per capita) in euros \\
\hline Equalizing grants & Equalizing grants (per capita) in euros \\
\hline Vote share incumbent & $\begin{array}{l}\text { Vote share of the incumbent SPD in the state election (in } \\
\text { percent) }\end{array}$ \\
\hline Vote share incumbent, local & Vote share of the SPD in local council elections (in percent) \\
\hline Mayor & Dummy variable equals one for mayors from the SPD \\
\hline Vote share CDU/FDP/Greens & $\begin{array}{l}\text { Vote share of the CDU, FDP or Greens in the state election } \\
\text { (in percent) }\end{array}$ \\
\hline Vote share difference & $\begin{array}{l}\text { Absolute vote share difference between the incumbent SPD } \\
\text { and the other main parties altogether (CDU, FDP, } \\
\text { Greens) in the state election (in percentage points) }\end{array}$ \\
\hline Vote share difference, local & $\begin{array}{l}\text { Absolute vote share difference between the SPD and the } \\
\text { other main parties altogether (CDU, FDP, Greens) in } \\
\text { local council elections (in percentage points) }\end{array}$ \\
\hline Incumbent representatives & $\begin{array}{l}\text { Number of the state incumbent party's members of } \\
\text { parliament born in the municipality divided by the total } \\
\text { population of that municipality (in percent) }\end{array}$ \\
\hline Fiscal capacity & $\begin{array}{l}\text { Tax revenues of the municipality (per capita) in euros: } \\
\text { property taxes, local business tax (both normalized with } \\
\text { standardized tax rates), share of federal income tax, share } \\
\text { of federal sales tax, compensatory payments; includes a } \\
\text { grant that guarantees a minimum level of fiscal capacity }\end{array}$ \\
\hline Population & Number of inhabitants \\
\hline Population density & Number of inhabitants per square kilometer \\
\hline Social expenditure & Social security expenditure (per capita) in euros \\
\hline Share of pupils & $\begin{array}{l}\text { Share of pupils in the total population (in percent); number } \\
\text { of pupils weighted with } 0.5 \text { for regular schools and } 1.5 \\
\text { for special schools }\end{array}$ \\
\hline Stationing forces & $\begin{array}{l}\text { Ratio of foreign stationing forces' relatives and non- } \\
\text { barracked soldiers to the population (in percent) }\end{array}$ \\
\hline Central place & $\begin{array}{l}\text { Ratio of the weighted population of the region of a central } \\
\text { place to the population of the central place (in percent) }\end{array}$ \\
\hline Municipality 1 & Dummy variable equals one for small municipalities \\
\hline Municipality 2 & $\begin{array}{l}\text { Dummy variable equals one for municipalities of } \\
\text { intermediate size }\end{array}$ \\
\hline Municipality 3 & $\begin{array}{l}\text { Dummy variable equals one for large cities that are not } \\
\text { county-independent }\end{array}$ \\
\hline Municipality 4 & Dummy variable equals one for county-independent cities \\
\hline Share of young population & Share of inhabitants younger than 18 (in percent) \\
\hline Share of old population & Share of inhabitants older than 59 (in percent) \\
\hline Share of unemployed & Share of unemployed in the total population (in percent) \\
\hline Region & $\begin{array}{l}\text { Dummy variables equal one for municipalities in the } \\
\text { individual region (East, West, Center, Palatinate; } \\
\text { reference category: Rhine-Hesse) }\end{array}$ \\
\hline
\end{tabular}

Sources: Ministry of the Interior, Sport, and Infrastructure Rhineland-Palatinate (Project grants), Statistical Office Rhineland-Palatinate (Equalizing grants, Fiscal capacity, Population, Area, Social expenditure, Pupils, Stationing forces, Central place, Municipality 1-3), State election administrator Rhineland-Palatinate (Vote shares, Vote share differences), own calculation (Mayor, Incumbent representatives, Region), Census (Share of young and old population), German employment office (Unemployment). 
Table 3: Descriptive statistics

\begin{tabular}{|c|c|c|c|c|c|}
\hline Variable & Mean & Std. Dev. & Min. & Max. & Obs. \\
\hline Project grants (per capita) & 29.81 & 57.01 & 0 & 710.42 & 2287 \\
\hline Equalizing grants (per capita) & 6.53 & 20.86 & 0 & 270.08 & 2287 \\
\hline Vote share incumbent (in percent) & 45.21 & 10.50 & 0 & 76.10 & 2287 \\
\hline $\begin{array}{l}\text { Vote share incumbent (in percent), } \\
\text { local }\end{array}$ & 10.34 & 16.66 & 0 & 70.40 & 2287 \\
\hline Mayor & 0.30 & 0.44 & 0 & 1 & 1265 \\
\hline Vote share CDU (in percent) & 33.62 & 11.99 & 3.20 & 100.00 & 2287 \\
\hline Vote share FDP (in percent) & 8.67 & 4.30 & 0 & 45.50 & 2287 \\
\hline Vote share Greens (in percent) & 3.85 & 2.40 & 0 & 20.90 & 2287 \\
\hline $\begin{array}{l}\text { Vote share difference } \\
\quad \text { (in percentage points) }\end{array}$ & 17.61 & 13.24 & 0 & 100.00 & 2287 \\
\hline $\begin{array}{l}\text { Vote share difference } \\
\quad \text { (in percentage points), local }\end{array}$ & 9.14 & 15.15 & 0 & 77.85 & 2287 \\
\hline $\begin{array}{l}\text { Incumbent representatives } \\
\text { (in percent) }\end{array}$ & 0.00 & 0.00 & 0 & 0.16 & 2287 \\
\hline Fiscal capacity (per capita) & 620.27 & 235.20 & 559.74 & 6182.16 & 2287 \\
\hline Population & 1766.73 & 7562.42 & 15.25 & 196317.50 & 2287 \\
\hline Population density & 150.19 & 163.63 & 7.16 & 2048.87 & 2287 \\
\hline Social expenditure (per capita) & 1.50 & 21.00 & 0 & 361.67 & 2287 \\
\hline Share of pupils (in percent) & 0.04 & 0.48 & 0 & 7.50 & 2287 \\
\hline Stationing forces (in percent) & 1.42 & 7.61 & 0 & 237.38 & 2287 \\
\hline Central place (in percent) & 1.20 & 4.26 & 0 & 72.30 & 2287 \\
\hline Municipality 1 & 0.98 & 0.14 & 0 & 1 & 2287 \\
\hline Municipality 2 & 0.01 & 0.11 & 0 & 1 & 2287 \\
\hline Municipality 3 & 0.00 & 0.06 & 0 & 1 & 2287 \\
\hline Municipality 4 & 0.01 & 0.07 & 0 & 1 & 2287 \\
\hline $\begin{array}{l}\text { Share of young population } \\
\text { (in percent) }\end{array}$ & 17.65 & 3.08 & 0 & 33.79 & 2287 \\
\hline Share of old population (in percent) & 25.20 & 4.44 & 5.09 & 52.91 & 2287 \\
\hline Share of unemployed (in percent) & 2.22 & 0.91 & 0 & 9.10 & 2287 \\
\hline East & 0.35 & 0.48 & 0 & 1 & 2287 \\
\hline West & 0.22 & 0.42 & 0 & 1 & 2287 \\
\hline Center & 0.15 & 0.36 & 0 & 1 & 2287 \\
\hline Palatinate & 0.22 & 0.41 & 0 & 1 & 2287 \\
\hline Rhine-Hesse & 0.06 & 0.24 & 0 & 1 & 2287 \\
\hline
\end{tabular}

Grants, fiscal capacity, and social expenditure measured in euros. The mean values of social expenditure and share of pupils are rather low, because these variables assume the value zero for individual types of municipalities that are not responsible for social expenditure or pupils. The value of stationing forces exceeds 100 percent when there are more stationing forces than inhabitants in a municipality (stationing forces are not considered as part of the population). 
Table 4: Regression results - marginal effects for the censored mean.

Dependent variable: ln Project grants (per capita) - discretionary, 2008-2011

\begin{tabular}{|c|c|c|c|c|}
\hline & $(1)$ & $(2)$ & $(3)$ & $(4)$ \\
\hline $\begin{array}{l}\text { Vote share incumbent } \\
\text { (in percent) }\end{array}$ & $\begin{array}{c}0.0193 * * * \\
(4.51)\end{array}$ & $\begin{array}{c}0.0154 * * * \\
(3.60)\end{array}$ & $\begin{array}{l}0.0153 * * * \\
(3.59)\end{array}$ & $\begin{array}{l}0.0142 * * * \\
(3.19)\end{array}$ \\
\hline $\begin{array}{l}\text { Incumbent representatives } \\
\text { (in percent) }\end{array}$ & & & $\begin{array}{c}10.17 * * * \\
(4.60)\end{array}$ & $\begin{array}{c}10.39 * * * \\
(4.58)\end{array}$ \\
\hline $\begin{array}{l}\text { In Fiscal capacity } \\
\text { (per capita) }\end{array}$ & & $\begin{array}{l}-0.134 \\
(-0.61)\end{array}$ & $\begin{array}{l}-0.134 \\
(-0.61)\end{array}$ & $\begin{array}{c}-0.0120 \\
(-0.05)\end{array}$ \\
\hline ln Population & & $\begin{array}{c}0.663 * * * \\
(11.63)\end{array}$ & $\begin{array}{l}0.662 * * * \\
(11.62)\end{array}$ & $\begin{array}{c}0.597 * * * \\
(10.05)\end{array}$ \\
\hline ln Population density & & $\begin{array}{c}-0.275^{* * *} \\
(-3.81)\end{array}$ & $\begin{array}{c}-0.275^{* * * *} \\
(-3.81)\end{array}$ & $\begin{array}{c}-0.154 * * \\
(-1.97)\end{array}$ \\
\hline $\begin{array}{l}\text { In Social expenditure } \\
\text { (per capita) }\end{array}$ & & $\begin{array}{l}0.847 \\
(1.59)\end{array}$ & $\begin{array}{l}0.835 \\
(1.60)\end{array}$ & $\begin{array}{c}1.374 * * \\
(2.34)\end{array}$ \\
\hline $\begin{array}{l}\text { Share of pupils } \\
\text { (in percent) }\end{array}$ & & $\begin{array}{c}-0.0502 \\
(-0.37)\end{array}$ & $\begin{array}{c}-0.0479 \\
(-0.36)\end{array}$ & $\begin{array}{c}-0.0485 \\
(-0.29)\end{array}$ \\
\hline $\begin{array}{l}\text { Stationing forces } \\
\text { (in percent) }\end{array}$ & & $\begin{array}{c}0.00158 \\
(0.26)\end{array}$ & $\begin{array}{c}0.00164 \\
(0.27)\end{array}$ & $\begin{array}{c}-0.00175 \\
(-0.32)\end{array}$ \\
\hline $\begin{array}{l}\text { Central place } \\
\quad \text { (in percent) }\end{array}$ & & $\begin{array}{l}0.0374 * * * \\
\quad(4.67)\end{array}$ & $\begin{array}{l}0.0365 * * * \\
\quad(4.60)\end{array}$ & $\begin{array}{l}0.0371 * * * \\
\quad(4.19)\end{array}$ \\
\hline Municipality 1 & & $\begin{array}{c}5.188 * \\
(1.66)\end{array}$ & $\begin{array}{c}5.141^{*} \\
(1.67)\end{array}$ & $\begin{array}{c}8.300 * * \\
(2.39)\end{array}$ \\
\hline Municipality 2 & & $\begin{array}{l}4.798 \\
(1.53)\end{array}$ & $\begin{array}{l}4.754 \\
(1.54)\end{array}$ & $\begin{array}{c}7.771 * * \\
(2.24)\end{array}$ \\
\hline Municipality 3 & & $\begin{array}{l}4.348 \\
(1.39)\end{array}$ & $\begin{array}{l}4.300 \\
(1.39)\end{array}$ & $\begin{array}{c}7.577 * * \\
(2.16)\end{array}$ \\
\hline $\begin{array}{l}\text { Share of young population } \\
\text { (in percent) }\end{array}$ & & & & $\begin{array}{l}-0.0165 \\
(-0.87)\end{array}$ \\
\hline $\begin{array}{l}\text { Share of old population } \\
\quad \text { (in percent) }\end{array}$ & & & & $\begin{array}{c}0.0143 \\
(1.18)\end{array}$ \\
\hline $\begin{array}{l}\text { Share of unemployed } \\
\quad \text { (in percent) }\end{array}$ & & & & $\begin{array}{c}-0.0560 \\
(-1.09)\end{array}$ \\
\hline Region East & & & & $\begin{array}{c}0.0994 \\
(0.59)\end{array}$ \\
\hline Region West & & & & $\begin{array}{l}-0.260 \\
(-1.53)\end{array}$ \\
\hline Region Center & & & & $\begin{array}{l}0.218 \\
(1.19)\end{array}$ \\
\hline Region Palatinate & & & & $\begin{array}{l}0.431 * * * \\
(2.62)\end{array}$ \\
\hline Observations & 2287 & 2287 & 2287 & 2287 \\
\hline Pseudo R² & 0.00272 & 0.0369 & 0.0371 & 0.0421 \\
\hline
\end{tabular}

Grants, fiscal capacity, and social expenditure measured in euros. All explanatory variables averaged over the years 2007-2010; Tobit models with standard errors robust to heteroskedasticity (Huber/White/sandwich standard errors); $\mathrm{z}$-statistics in parentheses; $* * * \mathrm{p}<0.01, * * \mathrm{p}<0.05, * \mathrm{p}<0.1$. 
Table 5: Regression results, robustness tests (core supporter) - marginal effects.

Dependent variable: $\ln$ Project grants (per capita) - discretionary, 2008-2011

\begin{tabular}{|c|c|c|c|c|}
\hline \multirow[t]{2}{*}{$\begin{array}{l}\text { Model } \\
\text { OLS }\end{array}$} & \multicolumn{2}{|c|}{$\begin{array}{l}\text { Coefficient (t/z-statistic) } \\
\text { of vote share incumbent } \\
\text { in state election } \\
\text { (in percent) }\end{array}$} & \multicolumn{2}{|c|}{$\begin{array}{l}\text { Coefficient (z-statistic) } \\
\text { of vote share incumbent } \\
\text { in local council elections } \\
\text { (in percent) / } \\
\text { mayor dummy }\end{array}$} \\
\hline & $0.01247 * * *$ & $(3.28)$ & & \\
\hline Negative binomial & $0.01489 * * *$ & $(3.42)$ & & \\
\hline Random-effects panel & $0.00518 * *$ & $(2.48)$ & & \\
\hline Tobit, small municipalities & $0.01399 * * *$ & $(3.16)$ & & \\
\hline Tobit, local council elections & & & 0.000329 & $(0.12)$ \\
\hline Tobit, state and local council elections & $0.01450 * * *$ & (3.18) & -0.00137 & $(-0.48)$ \\
\hline Tobit, mayor dummy & & & 0.000379 & $(0.00)$ \\
\hline Tobit, state elections and mayor dummy & $0.02038^{* * *}$ & $(2.91)$ & -0.16345 & $(-1.27)$ \\
\hline Tobit, vote share CDU & $-0.01050^{* *}$ & $(-2.52)$ & & \\
\hline Tobit, vote share FDP & -0.01610 & $(-1.45)$ & & \\
\hline Tobit, vote share Greens & -0.02320 & $(-1.21)$ & & \\
\hline \multicolumn{5}{|c|}{$\begin{array}{l}\text { Grants measured in euros. Models with standard errors robust to heteroskedasticity (Huber/White/sandwich } \\
\text { standard errors); } * * * \mathrm{p}<0.01, * * \mathrm{p}<0.05, * \mathrm{p}<0.1 \text {. }\end{array}$} \\
\hline \multicolumn{5}{|c|}{$\begin{array}{l}\text { Table 6: Regression results, robustness tests (swing voter) - marginal effects. } \\
\text { Dependent variable: In Project grants (per capita) - discretionary, 2008-2011 }\end{array}$} \\
\hline Model & \multicolumn{2}{|c|}{$\begin{array}{l}\text { Coefficient (t/z-statistic) } \\
\text { of vote share difference } \\
\text { in state election } \\
\text { (in percent) }\end{array}$} & \multicolumn{2}{|c|}{$\begin{array}{c}\text { Coefficient (z-statistic) } \\
\text { of vote share difference } \\
\text { in local council elections } \\
\text { (in percent) }\end{array}$} \\
\hline Tobit & -0.00367 & $(-1.04)$ & & \\
\hline $\begin{array}{l}\text { Tobit, vote share difference } \\
\text { plus } 5 \text { percentage points }\end{array}$ & -0.00119 & $(-0.34)$ & & \\
\hline $\begin{array}{l}\text { Tobit, vote share difference } \\
\text { plus } 10 \text { percentage points }\end{array}$ & 0.00195 & $(0.60)$ & & \\
\hline OLS & -0.00208 & $(-0.70)$ & & \\
\hline Negative binomial & -0.00382 & $(-1.09)$ & & \\
\hline Random-effects panel & 0.00022 & $(0.13)$ & & \\
\hline Tobit, small municipalities & -0.00366 & $(-1.04)$ & & \\
\hline Tobit, local council elections & & & 0.00378 & $(1.39)$ \\
\hline Tobit, state and local council elections & -0.00400 & $(-1.13)$ & 0.00410 & $(1.49)$ \\
\hline
\end{tabular}

Grants measured in euros. Models with standard errors robust to heteroskedasticity (Huber/White/sandwich standard errors); $* * * \mathrm{p}<0.01, * * \mathrm{p}<0.05, * \mathrm{p}<0.1$. It follows from simple calculations that one has to add 5 or 10 percentage points to the vote share difference before calculating its absolute value to describe that the number of swing voters is highest where the incumbent SPD is 5 or 10 percentage points weaker than the other main parties altogether. 
Table 7: Regression results, robustness tests - marginal effects.

Dependent variable: In Equalizing grants (per capita) - formula-based, 2008-2011

\begin{tabular}{lcccc}
\hline Model & $\begin{array}{c}\text { Coefficient (z-statistic) } \\
\text { of vote share incumbent } \\
\text { in state election } \\
\text { (in percent) }\end{array}$ & $\begin{array}{c}\text { Coefficient (z-statistic) } \\
\text { of vote share difference } \\
\text { in state election } \\
\text { (in percent) }\end{array}$ \\
\hline $\begin{array}{l}\text { Including control variables } \\
\begin{array}{l}\text { Tobit, core supporter } \\
\text { Tobit, swing voter }\end{array}\end{array}$ & 0.00188 & $(1.30)$ & & \\
\hline $\begin{array}{l}\text { Excluding control variables } \\
\text { Tobit, core supporter } \\
\text { Tobit, swing voter }\end{array}$ & 0.00350 & $(1.57)$ & $0.00197 *$ & $(1.81)$ \\
\hline
\end{tabular}

Grants measured in euros. Models with standard errors robust to heteroskedasticity (Huber/White/sandwich standard errors); *** $\mathrm{p}<0.01, * * \mathrm{p}<0.05, * \mathrm{p}<0.1$. 


\section{Appendix}

\section{Equalizing grants}

The equalizing grants $(E)$ support municipalities with fiscal need $(N)$ exceeding fiscal capacity $(C)$. The fiscal capacity is multiplied with a weighting factor $(x)$ depending on the municipality type. The equalization system balances 50 percent of the difference between fiscal need and fiscal capacity (if positive):

$E_{i}=\max \left\{0.5 \times\left(N_{i}-x_{i} \times C_{i}\right) ; 0\right\}$

\section{Fiscal need}

Six indicators determine the fiscal need $(N)$ of municipality $i$ :

- population $(n)$ multiplied with a weighting factor $(x)$,

- population density (area in square kilometers $(K)$ per capita) below the state average,

- $\quad$ social security expenditure $\left(G^{S}\right)$ per capita exceeding the state average,

- number of pupils in regular schools $\left(n^{R S}\right)$ and special schools $\left(n^{S S}\right)$,

- $\quad$ number of stationing forces $\left(n^{F}\right)$,

- the municipality's function as a central place providing public goods for inhabitants $\left(n^{C}\right)$ of adjacent municipalities that are multiplied with a weighting factor depending on the proximity of the municipality: near (includes the central place), intermediate, regional.

To express fiscal need in euros, the sum of the indicators is multiplied by a basic amount $(B A)$ in euros which depends on the funds approved for the total volume of equalizing grants:

$$
\begin{aligned}
& N_{i}=B A \times\left(x_{i} \times n_{i}+\max \left\{\left(\frac{K_{i}}{n_{i}}-\frac{K}{n}\right) \times 0.002 \times n_{i} ; 0\right\}+\max \left\{\frac{\frac{G_{i}^{S}}{n_{i}}-\frac{\bar{G}^{S}}{n}}{\frac{G^{S}}{n}} \times 0.002 \times\right.\right. \\
& \left.n_{i} ; 0\right\}+0.5 \times n_{i}^{R S}+1.5 \times n_{i}^{S S}+0.35 \times n_{i}^{F}+0.0385 \times n_{i}^{\text {C,near }}+0.011 \times n_{i}^{\text {, intermed }}+ \\
& \left.0.0033 \times n_{i}^{\text {,regional }}\right)
\end{aligned}
$$




\section{Fiscal capacity}

The fiscal capacity $(C)$ of municipality $i$ consists of normalized tax revenues $(R)$ and includes a grant $(A)$ that guarantees a minimum level $(a)$ of fiscal capacity $(76.2$ percent of the average tax revenues $(\bar{R})$ per capita in Rhineland-Palatinate).

Tax revenues include property taxes $\left(R^{P}\right)$ and the local business tax $\left(R^{B}\right)$, which are both normalized with standardized tax rates $\left(\bar{t}^{P}\right.$ and $\left.\bar{t}^{B}\right)$, the municipality's share of the federal income tax $\left(R^{I}\right)$, the municipality's share of the federal sales tax $\left(R^{S}\right)$, and compensatory payments $\left(R^{C}\right)$ :

$$
\begin{aligned}
& C_{i}=R_{i}+A_{i} \\
& A_{i}=\max \left\{\left(a \times \frac{\bar{R}}{n}-\frac{R_{i}}{n_{i}}\right) \times n_{i} ; 0\right\} \\
& R_{i}=\bar{t}^{P} \times \frac{R_{i}^{P}}{t_{i}^{P}}+\bar{t}^{B} \times \frac{R_{i}^{B}}{t_{i}^{B}}+R_{i}^{I}+R_{i}^{S}+R_{i}^{C}
\end{aligned}
$$

